\title{
Different Dietary Protein and PUFA Interventions Alter the Fatty Acid Concentrations, but Not the Meat Quality, of Porcine Muscle
}

\section{Dirk Dannenberger ${ }^{1, *}$, Karin Nuernberg ${ }^{1}$, Gerd Nuernberg ${ }^{1}$ and Antje Priepke ${ }^{2}$}

1 Research Unit of Muscle Biology and Growth and Genetics and Biometry, Leibniz Institute for Farm Animal Biology, Wilhelm-Stahl-Allee 2, 18196 Dummerstorf, Germany; E-Mails: knuernbg@fbn-dummerstorf.de (K.N.); gnuernbg@fbn-dummerstorf.de (G.N.)

2 Institute of Animal Production, State Institute for Agriculture and Fishing Research, Wilhelm-Stahl-Allee 2, 18196 Dummerstorf, Germany; E-Mail: a.priepke@lfa.mvnet.de

* Author to whom correspondence should be addressed; E-Mail: dannenberger@fbn-dummerstorf.de; Tel.: +49-38208-68884; Fax: +49-38208-68852.

Received: 6 July 2012; in revised form: 8 August 2012 / Accepted: 28 August 2012 / Published: 5 September 2012

\begin{abstract}
The present study investigated the effect of a reduced protein diet in combination with different vegetable oils (sunflower seed oil or linseed oil) on carcass traits, meat quality and fatty acid profile in porcine muscle. Forty male Landrace pigs were allocated into four experimental groups (each $n=8)$ and one control group $(n=8)$ at a live weight of approximately $60 \mathrm{~kg}$. The pigs were fed ad libitum from $60 \mathrm{~kg}$ to $100 \mathrm{~kg}$ live weight and restricted to $2.8 \mathrm{~kg}$ /day until they reached $120 \mathrm{~kg}$. In contrast to other studies, the intramuscular fat content (IMF) did not increase in animals of groups fed a reduced protein diet and vegetable oils. The IMF ranged between $1.2 \%$ and $1.4 \%$. The growth performance and meat quality of the longissimus muscle was not affected by the diet, but the average daily gain (ADG) and drip loss were affected. The muscle fatty acid concentrations were significantly affected by the diet, resulting in higher $n-3$ FA concentrations up to $113 \mathrm{mg} / 100 \mathrm{~g}$ muscle and lower $n-6 / n-3$ PUFA ratio for pigs fed linseed oil-containing high- and reduced protein diets, compared to sunflower seed oil-containing diets.
\end{abstract}

Keywords: reduced protein diet; linseed oil; sunflower oil; pig muscle; carcass traits; meat quality; fatty acids 


\section{Introduction}

The manipulation of the fatty acid composition of farm animal adipose tissues has been of great interest in recent years due to an increasing demand for the production of meat with desirable nutritional and technological qualities [1]. In contrast, the risks associated with the consumption of red meat to human health (e.g., cancer, diabetes and coronary heart disease) are currently a controversial topic $[2,3]$. To reduce the risk of cancer, the World Cancer Research Fund report recommends limiting the consumption of red meat to less than $500 \mathrm{~g}$ per week [4]. The majority of evidence for the association of red meat with cancer shows an increase in cancer risk for consumers with the highest level of red meat consumption; however, the results of most studies have not reached the level of statistical significance [5].

Currently, the main strategies for altering the nutritional profile of meat are genetic selection and/or dietary manipulation. Selection for lean growth and against higher back fat thickness has been a major goal of the pig industry. Dietary strategies used to customize the fatty acid composition of pig fat have proven very effective because dietary fatty acids can be incorporated into pig muscle and adipose tissues with few modifications [6-8]. The intramuscular fat (IMF) content of the pork is one important trait that influences meat quality characteristics, such as meat tenderness, juiciness, flavor and taste [1]. The role of IMF is of particular interest in pigs because genetic selection for lean pigs has reduced its level to below $1 \%$ IMF, compared with $2 \%-4 \%$ IMF in pig muscle fifty years ago. Several studies have suggested a favorable relationship between IMF and meat tenderness and juiciness and recommended that a minimum level of IMF is needed to maximize meat tenderness and consequently increase consumer acceptance [1,9]. Selected monounsaturated fatty acids (MUFAs) and polyunsaturated fatty acids (PUFAs) have a number of health benefits. The majority of the health benefits have been associated with $n$-3 PUFAs [10]. Several studies have investigated the effects of dietary PUFA (18:3n-3, linolenic acid; 18:2n-6, linoleic acid) source, mainly linseed, rapeseed or sunflower supplements, on pig performance and the fatty acid composition of pig tissues. It is known that feeding a linseed diet increases the content of $n$-3 PUFA and decreases the $n-6 / n-3$ PUFA ratio in all tissues, whereas feeding a sunflower seed diet leads to an increase in the $n$ - 6 PUFA contents [11,12]. An increase in the tissue $n$-3 PUFA has been observed under these conditions and has been correlated with the direct incorporation of dietary PUFA into pig tissues [7]. Animal nutrition has a major impact on fat quality and composition; for example, protein or lysine-deficient diets are known to increase the IMF contents in pigs. Several studies have shown that the IMF content in pigs can be increased without increasing back fat deposition by feeding pigs low protein diets during the growing or finishing phase. This might be due to a tissue-specific activation of the expression of lipogenic enzymes by the reduced protein diet [13-15].

The present study investigated the effects of feeding reduced protein diets in combination with different vegetable oils on carcass traits, meat quality and fatty acid profile in porcine muscle. To date, feeding reduced protein diets in combination with different vegetable oils to pigs has not been investigated. Based on the current knowledge, we hypothesized that the reduced protein diet in combination with linseed or sunflower seed oil would lead to an increase in the IMF content in porcine muscle without detrimental effects on meat quality. 


\section{Experimental Section}

\subsection{Experimental Design}

Forty male Landrace pigs (castrates) were used in the diet experiment. The animals were allocated into five feeding groups (each $n=8$ ) at a live weight of approximately $60 \mathrm{~kg}$ (Table 1 ). The pigs were fed ad libitum from $60 \mathrm{~kg}$ to $100 \mathrm{~kg}$ live weight and restricted to $2.8 \mathrm{~kg} /$ day until $120 \mathrm{~kg}$. The animals in the experimental groups (1-4) were fed two different levels of protein and two different types of vegetable oil. The animals in the control group were fed a regular diet without plant oil supplementation. The chemical and fatty acid compositions of the diets of the five groups - high protein diet with sunflower seed oil (HPD-SO), high protein diet with linseed oil (HPD-LO), reduced protein diet with sunflower seed oil (RPD-SO), reduced protein diet with linseed oil (RPD-LO) and control (CON) - are presented in Table 2. The HPD was formulated to contain an average of 19.5\% crude protein, and the RPD was formulated to contain an average of $15.5 \%$ crude protein. Sunflower seed oil (lipids high in linoleic acid, 18:2n-6) was used in the HPD-SO and RPD-SO diet groups, and linseed oil (lipids high in linolenic acid, 18:3n-3) was used in the HPD-LO and RPD-LO diet groups as fat sources (Table 2). The diets contained the same level of metabolizable energy (ME), approximately 13.6 MJ/kg. Thus, the energy/amino acid ratio was lower in the RPD groups. Acquisition of feed intake was performed for each single animal. The pigs were weighed once per week during the diet experiment. The pig experiment was carried out at the facilities of the University of Rostock, Faculty of Agricultural and Environmental Sciences. All experiments were conducted simultaneously to avoid seasonal effects between the different feeding groups. All diet composition components were analyzed before the beginning of the experiment as a basis for the final diet calculations. Diet samples were taken twice during the experiment and the chemical and fatty acid compositions were analyzed by a certificated laboratory (LUFA Rostock) according to VDLUFA guidelines. The results of the diet analyses are presented in Table 2. All animals were slaughtered at a target live weight of $120 \mathrm{~kg}$ in the abattoir of the Leibniz Institute for Farm Animal Biology in Dummerstorf (Germany). The slaughter and dressing procedures were performed in accordance with EU specifications. Immediately after slaughtering, tissue samples were collected from the right side of the carcass. Longissimus muscles used for the analysis of meat quality and fatty acid concentrations were taken from the 13th/14th rib and stored at $-80{ }^{\circ} \mathrm{C}$ until analysis.

Table 1. Experimental design and diet composition of the feeding groups.

\begin{tabular}{|c|c|c|c|c|c|}
\hline & $\begin{array}{c}\text { Group 1 } \\
\text { (HPD-SO) }\end{array}$ & $\begin{array}{c}\text { Group } 2 \\
\text { (HPD-LO) }\end{array}$ & $\begin{array}{c}\text { Group } 3 \\
\text { (RPD-SO) }\end{array}$ & $\begin{array}{c}\text { Group } 4 \\
\text { (RPD-LO) }\end{array}$ & $\begin{array}{c}\text { Group } 5 \\
\text { (CON) }\end{array}$ \\
\hline Number $(n)$ & 8 & 8 & 8 & 8 & 8 \\
\hline Feeding & $\begin{array}{l}\text { High protein diet } \\
\text { with sunflower } \\
\text { seed oil }\end{array}$ & $\begin{array}{l}\text { High protein } \\
\text { diet with } \\
\text { linseed oil }\end{array}$ & $\begin{array}{l}\text { Reduced protein } \\
\text { diet with sunflower } \\
\text { seed oil }\end{array}$ & $\begin{array}{l}\text { Reduced protein } \\
\text { diet with linseed } \\
\text { oil }\end{array}$ & Control \\
\hline \multicolumn{6}{|c|}{ Diet Composition * } \\
\hline Barley & 35.0 & 35.0 & 38.4 & 38.4 & 15.5 \\
\hline Wheat & 26.5 & 26.5 & 36.0 & 36.0 & 26.5 \\
\hline Soybean meal & 26.0 & 26.0 & 12.0 & 12.0 & 19.5 \\
\hline Rye & - & - & - & - & 19.0 \\
\hline Maize & - & - & - & - & 9.0 \\
\hline
\end{tabular}


Table 1. Cont.

\begin{tabular}{lccccc}
\hline Fiber mixture & 5.0 & 5.0 & 6.0 & 6.0 & 3.0 \\
Fattening & 3.0 & 3.0 & 3.0 & 3.0 & 7.5 \\
Supplement & - & 4.5 & - & 4.5 & - \\
Linseed oil & 4.5 & - & 4.5 & - & - \\
Sunflower oil & - & - & 0.1 & 0.1 & - \\
Lysine & * Percent based on original matter
\end{tabular}

Table 2. Results of chemical- and fatty acid composition analyses of the diets.

\begin{tabular}{|c|c|c|c|c|c|}
\hline & $\begin{array}{c}\text { Group 1 } \\
\text { (HPD-SO) }\end{array}$ & $\begin{array}{c}\text { Group 2 } \\
\text { (HPD-LO) }\end{array}$ & $\begin{array}{c}\text { Group } 3 \\
\text { (RPD-SO) }\end{array}$ & $\begin{array}{c}\text { Group } 4 \\
\text { (RPD-LO) }\end{array}$ & $\begin{array}{c}\text { Group } 5 \\
\text { (CON) }\end{array}$ \\
\hline \multicolumn{6}{|c|}{ Chemical Composition * } \\
\hline Dry matter & $\overline{9} 0.0$ & 88.7 & 89.8 & 89.6 & 89.3 \\
\hline Crude protein & 19.6 & 19.4 & 15.7 & 15.0 & 17.4 \\
\hline Crude fat & 5.2 & 5.7 & 5.9 & 6.3 & 3.4 \\
\hline Crude fiber & 4.7 & 4.6 & 5.3 & 5.5 & 4.2 \\
\hline Crude ash & 4.9 & 4.9 & 4.8 & 5.0 & 4.8 \\
\hline Starch & 36.9 & 36.2 & 40.0 & 40.7 & 40.1 \\
\hline $\mathrm{ME}(\mathrm{MJ} / \mathrm{kg})$ & 13.7 & 13.7 & 13.5 & 13.5 & 13.2 \\
\hline \multicolumn{6}{|l|}{ Amino Acids * } \\
\hline Lysine & 0.93 & 0.95 & 0.82 & 0.82 & 0.96 \\
\hline Methionine & 0.26 & 0.27 & 0.22 & 0.22 & 0.24 \\
\hline Cysteine & 0.31 & 0.31 & 0.26 & 0.27 & 0.30 \\
\hline Threonine & 0.60 & 0.61 & 0.48 & 0.45 & 0.56 \\
\hline \multicolumn{6}{|l|}{ Fatty Acids ${ }^{\text {a }}$} \\
\hline $14: 0$ & 0.12 & 0.11 & 0.12 & 0.11 & 0.35 \\
\hline $16: 0$ & 10.30 & 10.03 & 9.89 & 9.52 & 12.44 \\
\hline 18:0 & 3.38 & 3.84 & 3.43 & 3.75 & 1.84 \\
\hline $18: 1 c i s-9$ & 22.81 & 17.29 & 22.96 & 18.01 & 32.46 \\
\hline $18: 2 n-6$ & 52.94 & 29.43 & 51.69 & 31.77 & 39.07 \\
\hline $18: 3 n-3$ & 6.66 & 36.11 & 8.10 & 33.80 & 6.74 \\
\hline
\end{tabular}

* Percent based on original matter; ${ }^{\text {a }}$ proportion of total fatty acids.

\subsection{Methods}

\subsubsection{Meat Quality Parameters}

The $\mathrm{pH}$ values of the longissimus muscle samples were measured at $45 \mathrm{~min}$ and $24 \mathrm{~h}$ post mortem by stabbing a pH-Star CPU (Matthäus, Ebenried, Germany) into the left carcass side at the 7th/9th rib. The color of the longissimus muscle samples was measured at $24 \mathrm{~h}$ using a Minolta CR 200 (Minolta $\mathrm{GmbH}$, Ahrensburg, Germany) with triplicate measurements from a freshly cut surface using the parameters $\mathrm{L}^{*}$ (brightness), $\mathrm{a}^{*}$ (redness) and $\mathrm{b}^{*}$ (yellowness). The drip loss procedure has been described previously [16]. For the determination of Warner-Bratzler shear force (WBSF), one section of longissimus muscle $(2.54 \mathrm{~cm})$ was packed in transparent foil $24 \mathrm{~h}$ after slaughter, and then cooked in a water bath at $80{ }^{\circ} \mathrm{C}$ for $1 \mathrm{~h}$ to an internal temperature of $70{ }^{\circ} \mathrm{C}$. After cooling for $60 \mathrm{~min}$ at room temperature, 3-4 cores $(12.7 \mathrm{~mm})$ were cut from the steaks parallel to the muscle fiber orientation. The WBSF was measured with the Texture Analyser (Ahnsbeck) using a Warner-Bratzler blade $(2.8 \mathrm{~mm}$ wide) [17]. The intramuscular fat content (IMF) of the longissimus muscle samples were analyzed 
using a FoodScan ${ }^{\mathrm{TM}}$ Meat Analyser (FOSS Analytic, Hillerod, Denmark). The measurements were based on near infrared (NIR) transmission and covered 16 measurement points. The results are the average of 16 measurements. The IMF contents were expressed as g/100 g muscle.

\subsubsection{Fatty Acid Analysis}

Samples of $M$. longissimus were thawed at $4{ }^{\circ} \mathrm{C}$. After homogenization (Ultra Turrax, IKA, Staufen, Germany; T25, $3 \times 15 \mathrm{~s}, 12,000 \mathrm{rpm}$ ) and the addition of the fatty acid C19:0 as an internal standard, the total lipids were extracted in duplicate using chloroform/methanol $(2: 1, \mathrm{v} / \mathrm{v})$ at room temperature. The detailed sample preparation procedure has been described previously [7]. Briefly, all of the solvents contained of tert-butylhydroxytoluene (BHT) to prevent the oxidation of PUFAs. The final lipid extracts were redissolved in $300 \mu \mathrm{L}$ of toluene, and a $25 \mathrm{mg}$ aliquot was used for methyl ester preparation. Sodium methoxide in methanol was added to the samples, which were shaken in a $60{ }^{\circ} \mathrm{C}$ water bath for $10 \mathrm{~min}$. Subsequently, $1 \mathrm{~mL}$ of $14 \%$ boron trifluoride $\left(\mathrm{BF}_{3}\right)$ in methanol was added to the mixture, which was then shaken for an additional $10 \mathrm{~min}$ at $60{ }^{\circ} \mathrm{C}$. Finally, the solvent containing the FAMEs was reduced to dryness under an oxygen-free nitrogen stream, and the FAMEs were resuspended in $100 \mu \mathrm{L}$ of $n$-hexane and stored at $-18{ }^{\circ} \mathrm{C}$ until use for gas chromatography (GC) analysis. The fatty acid analysis of the muscle lipids was performed using capillary GC with a CP-Sil $88 \mathrm{CB}$ column $(100 \mathrm{~m} \times 0.25 \mathrm{~mm}$, Chrompack-Varian, Lake Forest, CA, USA) that was installed in a PerkinElmer gas chromatograph Autosys XL with a flame ionization detector (PerkinElmer Instruments, Shelton, CT, USA). The detailed GC conditions were recently described [18]. Hydrogen was used as the carrier gas at a flow rate of $1 \mathrm{~mL} / \mathrm{min}$. The split ratio was 1:20, and the injector and detector were set at $260^{\circ} \mathrm{C}$ and $280{ }^{\circ} \mathrm{C}$, respectively.

\subsubsection{Statistical Analysis}

The effects of the reduced protein diets and vegetables oils were estimated by one-way analysis of variance with fixed factor group (group 1 to 5) using the GLM procedure of the SAS software system $\left(\mathrm{SAS}^{\odot}\right.$ Systems, Release 9.2, SAS Institute Inc., Cary, NC, USA). The least squares means (LSMs) and the standard errors (SEM) of the LSMs are given in the tables. All post hoc tests were performed at a significance level of $p \leq 0.05$ using the Tukey-Kramer correction for multiple tests.

\section{Results and Discussion}

The results of growth performance and carcass trait measurements of male Landrace pigs are presented in Table 3. The average daily gain (ADG) was not affected by the experimental diets; however, the control group (CON) exhibited a lower ADG compared with experimental groups. The average daily feed intake (ADFI) was not affected by the diet. These results are consistent with recent studies investigating the effects of dietary protein level on growth performance and carcass traits in crossbred pigs $[13,14]$. Furthermore, the carcass traits, e.g., back fat, muscle area and liver and belly fat weights, were not influenced by the different experimental diets, except the hot carcass weight (Table 3). 
Table 3. Growth performance and carcass traits of Landrace pigs fed different diets.

\begin{tabular}{|c|c|c|c|c|c|c|}
\hline & $\begin{array}{c}\text { Group 1 } \\
\text { (HPD-SO) }\end{array}$ & $\begin{array}{c}\text { Group 2 } \\
\text { (HPD-LO) }\end{array}$ & $\begin{array}{l}\text { Group 3 } \\
\text { (RPD-SO) }\end{array}$ & $\begin{array}{c}\text { Group } 4 \\
\text { (RPD-LO) }\end{array}$ & $\begin{array}{c}\text { Group } 5 \\
\text { (CON) }\end{array}$ & Signific. \\
\hline & $\begin{array}{c}\mathrm{LSM}_{\mathrm{SEM}} \\
(n=8)\end{array}$ & $\begin{array}{c}\mathrm{LSM}_{\mathrm{SEM}} \\
(n=8)\end{array}$ & $\begin{array}{c}\mathrm{LSM}_{\mathrm{SEM}} \\
(n=8)\end{array}$ & $\begin{array}{c}\mathrm{LSM}_{\mathrm{SEM}} \\
(n=8)\end{array}$ & $\begin{array}{c}\mathrm{LSM}_{\mathrm{SEM}} \\
(n=8)\end{array}$ & \\
\hline Start weight (kg) & $68.8_{1.60}$ & $69.7_{1.60}$ & $69.4_{1.60}$ & $69.0_{1.60}$ & $69.2_{1.60}$ & 0.997 \\
\hline $\begin{array}{l}\text { Live weight at } \\
\text { slaughter }(\mathrm{kg})\end{array}$ & $120.6_{0.75}^{a}$ & $121.4_{0.75^{a}}$ & $123.2_{0.75}^{\mathrm{a}}$ & $120.6_{0.75}^{\mathrm{a}}$ & $117.8_{0.75}^{\mathrm{b}}$ & $<0.001$ \\
\hline $\mathrm{ADG}(\mathrm{g})$ & $831.4_{18.38}{ }^{\mathrm{a}}$ & $835.2_{18.30^{\mathrm{a}}}$ & $874.4_{18.38}{ }^{\mathrm{a}}$ & $840.6_{18.38}{ }^{\mathrm{a}}$ & $761.0_{18.38}{ }^{\mathrm{b}}$ & $<0.001$ \\
\hline ADFI $(g)$ & $3135.6_{49.25}$ & $3195.6_{49.25}$ & $3191.4_{49.25}$ & $3195.0_{49.25}$ & $3214.2_{49.25}$ & 0.832 \\
\hline $\begin{array}{l}\text { Hot carcass } \\
\text { weight, left }(\mathrm{kg})\end{array}$ & $49.0_{0.58}^{\mathrm{a}, \mathrm{b}}$ & $49.1_{0.58}^{\mathrm{a}, \mathrm{b}}$ & $50.5_{0.58}{ }^{a}$ & $49.3_{0.58}^{a, b}$ & $47.7_{0.58}{ }^{b}$ & 0.039 \\
\hline $\begin{array}{l}\text { Hot carcass } \\
\text { weight, right (kg) }\end{array}$ & $47.9_{0.38}{ }^{\mathrm{a}}$ & $48.2_{0.38}{ }^{\mathrm{a}}$ & $48.9_{0.38}{ }^{\mathrm{a}}$ & $47.8_{0.38^{\mathrm{a}}}$ & $46.4_{0.38^{b}}$ & $<0.001$ \\
\hline Liver weight (kg) & $1.7_{0.04}$ & $1.8_{0.04}$ & $1.7_{0.04}$ & $1.7_{0.04}$ & $1.8_{0.04}$ & 0.119 \\
\hline Belly weight (kg) & $1.5_{0.14}$ & $1.7_{0.14}$ & $1.5_{0.14}$ & $1.4_{0.14}$ & $1.5_{0.14}$ & 0.544 \\
\hline Back fat (mm) & $18.4_{1.03}$ & $19.3_{1.03}$ & $18.2_{1.03}$ & $19.2_{1.03}$ & $20.1_{1.03}$ & 0.710 \\
\hline Muscle area $\left(\mathrm{cm}^{2}\right)$ & $52.1_{2.01}$ & $50.3_{2.01}$ & $54.3_{2.01}$ & $51.1_{2.01}$ & $52.2_{2.01}$ & 0.692 \\
\hline
\end{tabular}

Different small letters $\left({ }^{\mathrm{a}},{ }^{\mathrm{b}}\right)$ denote significant effect of diet groups $(p \leq 0.05)$; ADG: average daily gain; ADFI: average daily feed intake.

Selected meat quality parameters of the longissimus muscles of pigs are presented in Table 4 . A number of studies have demonstrated that IMF and subcutaneous fat content might be manipulated independently through dietary means. For example, feeding a low protein diet increases the level of IMF with much smaller effects or no effects on subcutaneous fat content in pigs [9,13,14]. Inadequate dietary protein and/or lysine limit protein synthesis and increase the amount of energy available for fat deposition, resulting in higher IMF. In contrast, the IMF level in the Landrace pigs of the present study was not affected by the reduced protein level or by the use of linseed or sunflower seed oil in the diet. The IMF content ranged between $1.2 \%$ and $1.4 \%$ (Table 4). One possible explanation for unaffected IMF contents could be the smaller difference of protein level in the diets (19.4\%-19.6\% HPD) vs. $15.0 \%-15.7 \%$ in the RPD groups compared with other studies $(10 \%-13 \%$ low protein $v$ s. $18 \%-23 \%$ for the high protein diet) $[13,14]$. No significant effects were observed between the different diets for muscle color ( $\mathrm{L}^{*}, \mathrm{a}^{*}$, and $\left.\mathrm{b}^{*}\right)$, consistent with the results of recent studies by Alonso et al. [9] and Guo et al. [14]. However, one other study detected higher $\mathrm{L}^{*}, \mathrm{a}^{*}$ and $\mathrm{b}^{*}$ color values in the longissimus muscles of pigs fed low protein diets due to higher IMF contents and higher concentrations of 12:0 and 14:0 in the muscle, which makes the IMF less translucent and leads to a greater color saturation [19]. Neither reduced protein level nor dietary vegetable oil supplementation affected shear force (WBSF), pH value or cooking loss of the longissimus muscle (Table 4). Our results indicate that the pigs of all diet groups were in good condition pre-slaughter, resulting in normal $\mathrm{pH}$ development with a tendency toward better water holding characteristics in the muscles of HPD-LO pigs (lower drip loss). The lack of significant differences in IMF contents between the dietary treatments can contribute to the similar shear forces measured in the longissimus muscle (Table 4). Additionally, comparable muscle shear force seems to be a reflection of a uniform growth and development pattern, indicating similar sizes of muscle fibers and IMF contents. 
Table 4. Longissimus muscle quality of Landrace pigs fed different diets.

\begin{tabular}{|c|c|c|c|c|c|c|}
\hline & $\begin{array}{c}\text { Group 1 } \\
\text { (HPD-SO) }\end{array}$ & $\begin{array}{c}\text { Group 2 } \\
\text { (HPD-LO) }\end{array}$ & $\begin{array}{c}\text { Group 3 } \\
\text { (RPD-SO) }\end{array}$ & $\begin{array}{c}\text { Group 4 } \\
\text { (RPD-LO) }\end{array}$ & $\begin{array}{l}\text { Group } 5 \\
\text { (CON) }\end{array}$ & Signific. \\
\hline & $\begin{array}{c}\mathrm{LSM}_{\mathrm{SEM}} \\
(n=8)\end{array}$ & $\begin{array}{c}\mathrm{LSM}_{\mathrm{SEM}} \\
(n=8)\end{array}$ & $\begin{array}{c}\mathrm{LSM}_{\mathrm{SEM}} \\
(n=8)\end{array}$ & $\begin{array}{c}\mathrm{LSM}_{\mathrm{SEM}} \\
(n=8)\end{array}$ & $\begin{array}{c}\mathrm{LSM}_{\mathrm{SEM}} \\
(n=8)\end{array}$ & \\
\hline IMF (\%) & $1.3_{0.17}$ & $1.4_{0.17}$ & $1.4_{0.17}$ & $1.3_{0.17}$ & $1.2_{0.17}$ & 0.789 \\
\hline $\mathrm{pH}(45 \mathrm{~min})$ & $6.3_{0.06}$ & $6.4_{0.06}$ & $6.4_{0.06}$ & $6.4_{0.06}$ & $6.2_{0.06}$ & 0.078 \\
\hline $\mathrm{pH}(24 \mathrm{~h})$ & $5.4_{0.02}$ & $5.4_{0.02}$ & $5.4_{0.03}$ & $5.4_{0.02}$ & $5.4_{0.03}$ & 0.789 \\
\hline Color L* & $47.7_{0.56}$ & $48.3_{0.56}$ & $47.1_{0.56}$ & $48.5_{0.56}$ & $47.6_{0.56}$ & 0.380 \\
\hline$a^{*}$ & $7.6_{0.32}$ & $7.4_{0.32}$ & $7.4_{0.32}$ & $7.3_{0.32}$ & $7.7_{0.32}$ & 0.886 \\
\hline$b^{*}$ & $1.6_{0.23}$ & $1.6_{0.23}$ & $1.2_{0.23}$ & $1.4_{0.23}$ & $1.1_{0.23}$ & 0.440 \\
\hline Drip loss $(\mathrm{g} / 100 \mathrm{~g})$ & $3.5_{0.41}{ }^{2}$ & $2.6_{0.41} \mathrm{~b}$ & $2.8_{0.41}{ }^{-2}$ & $3.0_{0.41}{ }^{a}$ & $4.6_{0.41} \mathrm{~b}$ & 0.012 \\
\hline $\begin{array}{l}\text { Cooking loss } \\
(\mathrm{g} / 100 \mathrm{~g})\end{array}$ & $23.6_{0.80}$ & $21.0_{0.80}$ & $21.2_{0.80}$ & $21.9_{0.80}$ & $23.8_{0.80}$ & 0.440 \\
\hline $\begin{array}{l}\text { Shear force } \\
\left(\mathrm{kg} / \mathrm{cm}^{2}\right)\end{array}$ & $5.2_{0.27}$ & $4.7_{0.27}$ & $5.5_{0.27}$ & $4.9_{0.27}$ & $4.8_{0.27}$ & 0.189 \\
\hline
\end{tabular}

Different small letters $\left({ }^{\mathrm{a}},{ }^{\mathrm{b}}\right)$ denote significant effect of diet groups $(p \leq 0.05)$; IMF: intramuscular fat.

The effects of dietary PUFA supplements, mainly linseed, rapeseed or sunflower seed oils, cake or seeds, on pig performance and fatty acid composition of tissues have been investigated intensively. It is known that feeding a linseed diet increases the $n-3$ PUFA content and decreases the $n-6 / n-3$ fatty acid ratio in all tissues, whereas feeding sunflower seed leads to an increase in the $n$ - 6 PUFA contents due to the direct incorporation of the dietary PUFA into pig tissues [7,11,20,21]. The single fatty acid concentrations of the longissimus muscle in pigs are shown in Table 5, and the selected total fatty acid concentrations are presented in Figure 1. The muscle fatty acid concentrations of the present study appeared to be significantly affected by the diet, resulting in significantly higher $n$-3 FA concentrations (up to $113 \mathrm{mg} / 100 \mathrm{~g}$ muscle) in linseed oil-containing high- and reduced protein diets, compared to sunflower seed oil diets; only docosahexaenoic acid (22:6n-3, DHA) was not significantly increased. In most of the previous studies, the use of $n$-3 PUFA-rich vegetable oils showed no or only small effects on the intramuscular DHA level [7,15,21,22]. Feeding linseed oil-containing HPD- and RPD diets significantly decreased the concentration of single and total $n-6$ PUFA in longissimus muscle of pigs compared with the sunflower seed oil-containing fed groups and the control group (Table 5 and Figure 1). Consequently, the high level of n-3 PUFAs, which are beneficial for human nutrition, and the lower level of $n-6$ PUFAs in pigs fed linseed oil-containing diets caused a beneficially low $n-6 / n-3$ PUFA ratio in the muscle compared with sunflower seed oil containing diets and the control diet. The $n-6 / n-3$ PUFA ratio was 1.8:1 in muscle of pigs fed linseed oil containing HPD- and RPD diets, which corresponds to the $n-6 / n-3$ PUFA ratio recommended by the German Nutrition Society $(\leq 5: 1)[23]$. The concentrations of single saturated and total saturated fatty acids (SFA) were not affected by either the protein content or the type of oil supplement (Table 5 and Figure 1). Other studies showed that feeding a low protein diet with an increased IMF level resulted in elevated concentrations of 14:0, 16:0 and total SFAs, as a reflection of the higher IMF contents [19]. Additionally, oleic acid (18:1 cis-9), the most abundant fatty acid in pig muscles, and total monounsaturated fatty acids (MUFAs) were not affected by the different dietary treatments. 
Table 5. Fatty acid concentrations (longissimus muscle, $\mathrm{mg} / 100 \mathrm{~g}$ muscle) of Landrace pigs fed different diets.

\begin{tabular}{|c|c|c|c|c|c|c|}
\hline & $\begin{array}{c}\text { Group } 1 \\
\text { (HPD-SO) }\end{array}$ & $\begin{array}{c}\text { Group } 2 \\
\text { (HPD-LO) }\end{array}$ & $\begin{array}{c}\text { Group } 3 \\
\text { (RPD-SO) }\end{array}$ & $\begin{array}{c}\text { Group } 4 \\
\text { (RPD-LO) }\end{array}$ & $\begin{array}{c}\text { Group } 5 \\
\text { (CON) }\end{array}$ & Signific. \\
\hline & $\begin{array}{c}\mathrm{LSM}_{\mathrm{SEM}} \\
(n=8)\end{array}$ & $\begin{array}{c}\mathrm{LSM}_{\mathrm{SEM}} \\
(n=8)\end{array}$ & $\begin{array}{c}\mathrm{LSM}_{\mathrm{SEM}} \\
(n=8)\end{array}$ & $\begin{array}{c}\mathrm{LSM}_{\mathrm{SEM}} \\
(n=8)\end{array}$ & $\begin{array}{c}\mathrm{LSM}_{\mathrm{SEM}} \\
(n=8)\end{array}$ & \\
\hline Sum FA & $1403.4_{150.4}$ & $1517.3_{150.4}$ & $1486.3_{150.4}$ & $1410.6_{150.4}$ & $1292.9_{150.4}$ & 0.852 \\
\hline $12: 0$ & $1.2_{0.18}$ & $1.4_{0.18}$ & $1.3_{0.18}$ & $1.2_{0.18}$ & $1.0_{0.18}$ & 0.633 \\
\hline 14:0 & $16.8_{2.76}$ & $20.5_{2.76}$ & $19.2_{2.76}$ & $16.9_{2.76}$ & $15.1_{2.76}$ & 0.667 \\
\hline 16:0 & $331.8_{40.15}$ & $368.2_{40.15}$ & $354.2_{40.15}$ & $321.0_{40.15}$ & $302.9_{40.15}$ & 0.792 \\
\hline 16:1 & $38.7_{6.45}$ & $44.2_{6.45}$ & $41.4_{6.45}$ & $37.9_{6.45}$ & $37.6_{6.45}$ & 0.941 \\
\hline 18:0 & $162.9_{19.13}$ & $183.5_{19.13}$ & $183.3_{19.13}$ & $164.3_{19.13}$ & $154.5_{19.13}$ & 0.761 \\
\hline 18:1cis-9 & $475.3_{61.02}$ & $508.4_{61.02}$ & $500.6_{61.02}$ & $469.4_{61.02}$ & $467.4_{61.02}$ & 0.980 \\
\hline 18:1cis-11 & $55.8_{7.70}$ & $60.7_{7.70}$ & $57.4_{7.70}$ & 53.27 .70 & $57.5_{7.70}$ & 0.975 \\
\hline $18: 2 n-6$ & $201.3_{10.70}^{\mathrm{a}}$ & $148.2_{10.70}^{\mathrm{b}}$ & $203.9_{10.70}^{\mathrm{a}}$ & $163.0_{10.70^{\mathrm{a}, \mathrm{b}}}$ & $139.3_{10.70}{ }^{\mathrm{b}}$ & $<0.001$ \\
\hline $18: 3 n-3$ & $13.1_{4.05^{\mathrm{a}}}$ & $65.2_{4.05}{ }^{b}$ & $16.8_{4.05}^{\mathrm{a}}$ & $66.8_{4.05}^{b}$ & $10.3_{4.05^{\mathrm{a}}}$ & $<0.001$ \\
\hline $20: 2 n-6$ & $5.1_{0.40}{ }^{a}$ & $3.8_{0.40} a, b$ & $5.7_{0.40} \mathrm{a,c}$ & $4.2_{0.40} \mathrm{a}, \mathrm{b}$ & $3.3_{0.40} \mathrm{~b}$ & $<0.001$ \\
\hline $20: 3 n-6$ & $6.3_{0.22}{ }^{a}$ & $5.5_{0.22} \mathrm{a}, \mathrm{b}$ & $6.4_{0.22}{ }^{\mathrm{a}}$ & $5.6_{0.22}{ }^{a, b}$ & $7.0_{0.22}{ }^{\mathrm{a}}$ & $<0.001$ \\
\hline $20: 3 n-3$ & $2.5_{0.63}{ }^{\mathrm{a}}$ & $8.2_{0.63}{ }^{\mathrm{b}}$ & $3.3_{0.63}{ }^{\mathrm{a}}$ & $8.8_{0.63}{ }^{\mathrm{b}}$ & $1.8_{0.63}{ }^{\mathrm{a}}$ & $<0.001$ \\
\hline $20: 4 n-6$ & $43.4_{1.01}{ }^{\mathrm{a}}$ & $29.4_{1.01}{ }^{b}$ & $41.4_{1.01}{ }^{\mathrm{a}}$ & $29.99_{1.01} \mathrm{~b}$ & $39.9_{1.01}{ }^{\mathrm{a}}$ & $<0.001$ \\
\hline $20: 5 n-3$ & $4.4_{0.54}{ }^{\mathrm{a}}$ & $17.9_{0.54} \mathrm{~b}$ & $5.1_{0.54}{ }^{\mathrm{a}}$ & $19.7_{0.54} \mathrm{~b}$ & $6.3_{0.54}{ }^{\mathrm{a}}$ & $<0.001$ \\
\hline $22: 4 n-6$ & $4.8_{0.14}{ }^{\mathrm{a}}$ & $2.3_{0.14}{ }^{b}$ & $4.6_{0.14}{ }^{\mathrm{a}}$ & $2.0_{0.14}{ }^{b}$ & $4.3_{0.14}{ }^{\mathrm{a}}$ & $<0.001$ \\
\hline $22: 5 n-3$ & $8.5_{0.29}{ }^{\mathrm{a}}$ & $13.8_{0.29} \mathrm{~b}$ & $9.4_{0.29}{ }^{\mathrm{a}}$ & $14.0_{0.29} \mathrm{~b}$ & $8.9_{0.29^{a}}{ }^{-14}$ & $<0.001$ \\
\hline $22: 6 n-3$ & $3.7_{0.23}{ }^{\mathrm{a}}$ & $3.5_{0.23}{ }^{\mathrm{a}}$ & $3.6_{0.23}{ }^{\mathrm{a}}$ & $3.6_{0.23}{ }^{a}$ & $4.7_{0.23}{ }^{b}$ & 0.005 \\
\hline
\end{tabular}

Different small letters $\left({ }^{\mathrm{a}},{ }^{\mathrm{b}}\right)$ denote significant effect of diet groups $(p \leq 0.05)$.

Figure 1. Total fatty acid concentrations (longissimus muscle) of Landrace pigs fed different diets.

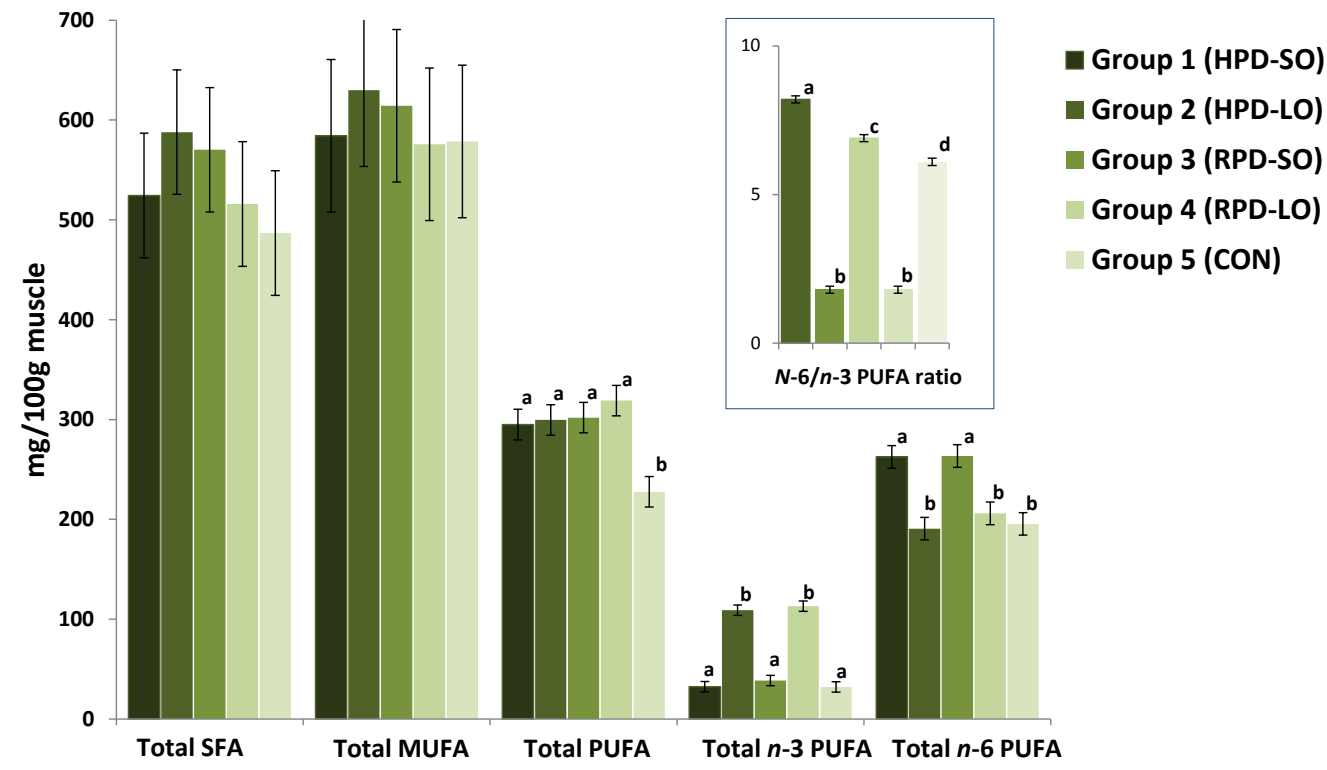

Different small letters $\left({ }^{\mathrm{a}}, \mathrm{b}, \mathrm{c}, \mathrm{d}\right)$ denote significant effect of diet groups $(p \leq 0.05)$; total SFA: $10: 0+11: 0+12: 0+13: 0+14: 0+15: 0+16: 0+17: 0+18: 0+20: 0+21: 0+22: 0+23: 0+24: 0$ total MUFA: $14: 1+15: 1+16: 1+17: 1+18: 1 t+18: 1 c 9+\mathrm{C} 18: 1 c 11+\mathrm{C} 22: 1+\mathrm{C} 24: 1$; total PUFA: $18: 2 t+18: 2 n-6+18: 3 n-3+18: 4 n-3+20: 3 n-6+20: 4 n-6+20: 5 n-3+22: 1+22: 4 n-6+22: 5 n-3+$ $22: 6 n-3+c 9$, trllCLA $+18: 3 n-6+20: 2 n-6+20: 3 n-3+22: 2 n-6 ;$ total $n-3$ PUFA: $20: 3 n-3+22: 6 n-3+$ $22: 5 n-3+20: 5 n-3+18: 4 n-3+18: 3 n-3$; total $n-6$ PUFA: $22: 2 n-6+20: 2 n-6+18: 3 n-6+22: 4 n-6+$ $20: 3 n-6+18: 2 n-6+20: 4 n-6$. 


\section{Conclusions}

In contrast to our hypothesis, a reduced protein diet in combination with linseed or sunflower oil did not lead to an increase in the IMF content of the longissimus muscle of male Landrace pigs. However, diets supplemented with linseed oil allow the production of pork meat with a high $n-3$ fatty acid content and low $n-6 / n-3$ PUFA ratio, which is beneficial for human nutrition. Additionally, feeding pigs a reduced protein diet in combination with linseed or sunflower oil had no detrimental effects on muscle meat quality.

\section{Acknowledgments}

The authors wish to thank B. Jentz, M. Dahm, U. Bretschneider and H. Peters of the Department of Muscle Biology and Growth who collaborated in the sample preparation, HRGC and meat quality measurements.

\section{Conflicts of Interest}

The authors declare no conflicts of interest.

\section{References}

1. Wood, J.D.; Enser, M.; Fisher, A.V.; Nute, G.R.; Sheard, P.R.; Richardson, R.I.; Hughes, S.I.; Whittington, F.M. Fat deposition, fatty acid composition and meat quality: A review. Meat Sci. 2008, 78, 343-358.

2. Corpet, D.E. Red meat and colon cancer: Should we become vegetarians, or can we make meat safer? Meat Sci. 2011, 89, 310-316.

3. Fretts, A.M.; Howard, B.V.; McKnight, B.; Duncan, G.E.; Beresford, S.A.A.; Mete, M.; Eilat-Adar, S.; Zhang, Y.; Siscovick, D.S. Associations of processed meat and unprocessed red meat intake with incident diabetes: The strong heart family study. Am. J. Clin. Nutr. 2012, 95, 752-758.

4. World Cancer Research Fund, American Institute for Cancer Research. Policy and Action for Cancer Prevention; WCRF and AICR: Washington, DC, USA, 2009.

5. Wyness, L.; Weichselbaum, E.; O’Connor, A.; Williams, E.B.; Rilex, H.; Stanner, S. Red meat in the diet: An update. Nutr. Bull. 2010, 36, 34-77.

6. Duran-Montge, P.; Realini, C.E.; Barroeta, A.C.; Lizardo, R.G.; Esteve-Garcia, E. De novo fatty acid synthesis and balance of fatty acids of pigs fed different fat sources. Livest. Sci. 2010, 132, 157-164.

7. Nuernberg, K.; Nuernberg, G.; Dannenberger, D. Effect of extruded linseed on growth and lipids of muscle and back fat in pigs. Fleischwirtschaft 2011, 91, 88-92.

8. Sobotka, W.; Flis, M.; Antoszkiewicz, Z.; Lipinski, K.; Zdunczyk, Z. Effect of oat by-product antioxidants and vitamin $\mathrm{E}$ on the oxidative stability of pork from pigs fed diets supplemented with linseed oil. Arch. Amin. Nutr. 2012, 66, 27-38.

9. Alonso, A.; Campo, M.M.; Provincial, L.; Roncales, P.; Beltran, J.A. Effect of protein level in commercial diets on pork meat quality. Meat Sci. 2010, 85, 7-14.

10. Calder, P.C.; Dangour, A.D.; Diekman, C.; Eilander, A.; Koletzko, B.; Meijer, G.W.; Mozaffarian, D.; Niinikoski, H.; Osendarp, S.J.; Pietinen, P.; et al. Essential fats for future health. Proceedings of the 9th Unilever Nutrition Symposium, 26-27 May 2010. Eur. J. Clin. Nutr. 2010, 64, S1-S13. 
11. Realini, C.E.; Duran-Montge, P.; Lizardo, R.; Gispert, M.; Oliver, M.A.; Esteve-Garcia, E. Effect of source of dietary fat on pig performance, carcass characteristics and carcass fat content, distribution and fatty acid composition. Meat Sci. 2010, 85, 606-612.

12. Juarez, M.; Dugan, M.E.R.; Aldai, N.; Aalhus, J.L.; Patience, J.F.; Zijlstra, R.T.; Beaulieu, A.D. Feeding co-extruded flaxseed to pigs: Effect of duration and feeding level on growth performance and backfat fatty acid composition of grower-finisher pigs. Meat Sci. 2010, 84, 578-584.

13. Doran, O.; Moule, S.K.; Teye, G.A.; Whittington, F.M.; Hallett, K.G.; Wood, J.D. A reduced protein diet induces stearoyl-CoA desaturase protein expression in pig muscle but not in subcutaneous adipose tissue: relationship with intramuscular lipid formation. Br. J. Nutr. 2006, 95, 609-617.

14. Guo, X.; Tang, R.; Wang, W.; Liu, D.; Wang, K. Effects of dietary protein/carbohydrate ratio on fat deposition and gene expression of peroxisome proliferator activated receptor $\gamma$ and heart fatty acid-binding protein of finishing pigs. Livest. Sci. 2011, 140, 111-116.

15. Guillevic, M.; Kouba, M.; Mourot, J. Effect of a linseed diet or sunflower diet on performances, fatty acid composition, lipogenic enzyme activity and stearoyl-CoA-desaturase activity in the pig. Livest. Sci. 2009, 124, 288-294.

16. Kuechenmeister, U.; Kuhn, G.; Ender, K. Seasonal effects on $\mathrm{Ca}^{2+}$ transport of sarcoplasmatic reticulum and meat quality of pigs with different malignant hyperthermia status. Meat Sci. 2000, 55, 239-245.

17. Dannenberger, D.; Nuernberg, K.; Nuernberg, G.; Ender, K. Carcass- and meat quality of pasture vs. concentrate fed German Simmental and German Holstein bulls. Arch. Tierz. 2006, 49, 315-328.

18. Shen, X.; Dannenberger, D.; Nuernberg, K.; Nuernberg, G.; Zhao, R. Trans-18:1 and CLA isomers in rumen and duodenal digesta of bulls fed $n-3$ and n-6 PUFA-based diets. Lipids 2011, 46, 831-841.

19. Teye, G.A.; Sheard, P.R.; Whittington, F.M.; Nute, G.R.; Stewart, A.; Wood, J.D. Influence of dietary oils and protein level on pork quality. 1. Effects on muscle fatty acid composition, carcass, meat and eating quality. Meat Sci. 2006, 73, 157-165.

20. Kouba, M.; Mourot, J. A review of nutritional effects on fat composition of animal products with special emphasis on $n-3$ polyunsaturated fatty acids. Biochimie 2011, 93, 13-17.

21. Raes, K.; de Smet, S.; Demeyer, D. Effect of dietary fatty acids on incorporation of long chain polyunsaturated fatty acids and conjugated linoleic acid in lamb, beef and pork meat: A review. Amin. Feed Sci. Technol. 2004, 113, 199-221.

22. Cherfaoui, M.; Durand, D.; Bonnet, M.; Cassar-Malek, I.; Bauchart, D.; Thomas, A.; Gruffat, D. Expression of enzymes and transcription factors involved in the $n-3$ long chain PUFA biosynthesis in Limousin bull tissues. Lipids 2012, 47, 391-401.

23. German Nutrition Society (DGE). D-A-CH Referenzwerte für die Nährstoffzufuhr; Umschau-Verlag: Frankfurt am Main, Germany, 2012.

2012 by the authors; licensee MDPI, Basel, Switzerland. This article is an open access article distributed under the terms and conditions of the Creative Commons Attribution license (http://creativecommons.org/licenses/by/3.0/). 